\title{
Das multi bonitezas da Cultura na Educação
}

A edição no. 29 da Revista Dialogia, Educação e Multiculturalismo, apresenta uma abordagem reflexivamente ampliadora sobre os conceitos de cultura e educação em seus possíveis diálogos. O multiculturalismo, tema altamente relevante na atualidade, tem sido, por vezes, submetido a confusões conceituais portadoras de teores discursivos tendenciosamente exclusivistas disfarçados de diversidade. Nesse sentido é que o radical latino multi (muitos, numerosos) surge nesta edição, primordialmente, como referência a destacar, sobretudo, o aspecto de signo plural, diversificador, relacionado à cultura e à educação.

Partimos, inicialmente, em viagem multicultural internacionalizadora, do Brasil aos Estados Unidos, em entrevista com a Profa. Dra. Flavia Iuspa, educadora e diretora de programas e iniciativas internacionais do Departamento de Pós-Graduação em Ensino e Aprendizagem da Florida International University (FIU). Pesquisadora das obras de Paulo Freire e John Dewey, ela nos revela, entre outras importantes questões sobre educação, multiculturalismo e internacionalização, como está sendo atuar como educadora e pesquisadora em uma universidade norte-americana de viés multiculturalista em face de lideranças governamentais que se mostram predominantemente antagônicas à diversidade cultural como potência educacional e social.

Compondo o dossiê, temos um primeiro aceno da riqueza referencial do multi cultural e educador com o artigo do Prof. Dr. Iury Carlos Bueno. Amparado por Roland Barthes como anfitrião intelectual, transporta-nos em viagem pelo outro lado do planeta, ao império dos signos da cultura oriental, onde a fotografia e o haicai surgem como destacáveis expressões estéticas educadoras do olhar e dos demais sentidos.

A Profa. Dra. Maria Aparecida Costa dos Santos nos conduz, a seguir, pela imensidão multi do universo Hip-Hop. O anfitrião intelectual nessa viagem é Paulo Freire. Tomando principalmente como suporte de análise os princípios epistemológicos da Pedagogia do Oprimido, ela discute a constituição do Hip-Hop como movimento social e cultural, estabelecendo suas relações com a perspectiva multicultural. Fenômeno mundial singular a envolver jovens e adultos das perife- 
rias de todo o planeta, o Hip-Hop se revela também como processo educador e de resistência sociocultural.

O processo de decolonialidade das estruturas de poder colonial, ainda dominantes nas instituições educativas, como reflexo da colonialidade do poder, do saber, do gênero, da sexualidade e das relações sociais hierárquicas de dominação é abordado pelo Prof. Dr. Manuel Tavares em parceria com a professora e doutoranda Sandra Rosa Gomes. Em seu percurso fundamentador, consideram os conceitos de pedagogia, interculturalidade e decolonialidade como indissociáveis, sendo nas práticas sociais, políticas e educativas que se tecem os caminhos da decolonialidade.

A Dra. Isabel Jungk realiza, de maneira singular, uma perspectiva filosófica sobre o conceito de multi. Fundamentando-se na obra do filósofo e lógico Charles Sanders Peirce, aborda a diversidade cultural em diálogo com a educação a partir de uma perspectiva semiótica. Por tal percurso, reflete o desenvolvimento de uma lógica mais abrangente sobre a realidade humana, capaz de integrar diversos pontos de vista de maneira inclusiva e, dessa forma, assimilar diferenças culturais e científicas de forma inteligível em meio à heterogeneidade social contemporânea.

A continuidade de uma pesquisa qualitativa em andamento, baseada em diferentes modelos de multiculturalismo, envolvendo observação e análise das relações interpessoais e educativas entre docentes e alunos imigrantes bolivianos e descendentes, e entre os demais alunos do ensino fundamental II, em uma escola estadual da região central de São Paulo são apresentados na sequência pela Profa. Dra. Elaine Teresinha Dal Mas Dias e pelo Prof. Dr. João Clemente Souza Neto. Estudo relevante não somente ao dossiê desta edição, mas também para se pensar de modo mais aprofundado, conceitualmente e na prática educacional, a convivência multicultural com o outro.

O Prof. Dr. Antonio de Assis Cruz Nunes, em parceria com a mestranda Andréa Luisa Frazão Silva e o mestrando Luis Félix de Barros Vieira Rocha trazem um recorte altamente relevante ao dossiê, ao tratarem a questão legislativa referente à Lei $n^{0} 10.639 / 2003$, constituindo-se como forte instrumento político e, sobretudo, pedagógico para o combate do preconceito e da discriminação racial no contexto do multiculturalismo crítico ou da interculturalidade. Primeiramente, traçam uma breve trajetória histórica de algumas ações dos movimentos sociais negros no Brasil até a aprovação da Lei. Para tanto, apoiam-se no Plano Nacional de Implementação das Diretrizes Curriculares Nacionais para Educação das Relações 
Étnico-Raciais e para o Ensino de História e Cultura Afrobrasileira e Africana e em autores que tratam a temática das relações étnico-raciais.

Fechando o dossiê, o tema multiculturalismo e educação se destaca a partir de narrativas de professores sobre preconceito e abordagens culturais na escola, em artigo apresentado pela Profa. Dra. Maria Cristina Ferreira dos Santos e pelo Prof. Ms. Caio Roberto Siqueira Lamego. Considerando a importância da compreensão de dinâmicas de sujeitos socioculturais na escola, mostram como professores abordam questões culturais e situações de preconceito e discriminação na escola, a partir de narrativas evidenciadoras de experiências de preconceito e discriminação racial, religiosa, de gênero e sexualidade e a utilização de práticas dialógicas pelos professores ao abordar questões culturais no cotidiano escolar. Contribuem, assim, com reflexões sobre questões culturais que permeiam a escola e destacam práticas dialógicas como estratégia para uma escola menos excludente.

Os artigos que se seguem ao dossiê compõem todo um conjunto complementar igualmente relevante para se pensar conceitos e práticas educacionais pelo viés do multi. Reforma educacional, inclusão de recursos tecnológicos nas práticas docentes, estratégias de aprendizagem, ações políticas dos jovens no âmbito reconfigurador da ordem escolar e cultura dos super-heróis como parte de um projeto para a pré-escola são alguns dos temas de reflexão nesse segmento.

As resenhas que fecham esta edição nos convidam a leituras instigantes quanto à atualização de saberes sobre educação. Em consonância com a temática do dossiê, propõem reflexões e fundamentações teóricas e práticas sobre o contexto educacional ampliando-se dimensões para além dele, sugerindo novas possibilidades de pensamentos e ações educativas bem pensantes para o século XXI, em diálogo com metas, políticas educacionais e currículos de outras culturas.

Considerando o multi sobretudo como boniteza na cultura e na educação, conforme o uso poeticamente singular com que Paulo Freire utiliza essa adjetivação, aproveitamos para, oportunamente, aqui homenageá-lo na condição de mais novo Patrono da Educação Paulistana, eleito em junho de 2018, título ao qual se soma o de Patrono da Educação Brasileira obtido em 2012.

Boas multi leituras! Ana Maria Haddad Baptista e Márcia Fusaro 
